DOI: https://doi.org/10.47405/mjssh.v6i3.689

\begin{tabular}{|c|c|}
\hline & Malaysian Journal of Social Sciences and Humanities (MJSSH) \\
\hline 32 & Volume 6, Issue 3, March 2021 \\
\hline 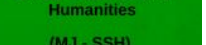 & e-ISSN : 2504-8562 \\
\hline & $\begin{array}{l}\text { Journal home page: } \\
\text { www.msocialsciences.com }\end{array}$ \\
\hline
\end{tabular}

\title{
Kemahiran Proses Sains Tahap Empat: Satu instrumen untuk Pelajar Tingkatan Empat Sekolah Menengah
}

\author{
Chai Wan Luen', Siew Nyet Moi @ Sopiah Abdullah1, Lee Bih Nih1
}

${ }^{1}$ Fakulti Psikologi dan Pendidikan, Universiti Malaysia Sabah (UMS)

Correspondence: Siew Nyet Moi @ Sopiah Abdullah (sopiah@ums.edu.my)

\begin{abstract}
Abstrak
Kajian ini bertujuan menentukan kesahan dan kebolehpercayaan instrumen Ujian Kemahiran Proses Sains Tahap Empat (UKPST4) menggunakan Model Pengukuran Rasch. UKPST4 dibangunkan untuk mengukur penguasaan Kemahiran Proses Sains (KPS) Tahap Empat pelajar Tingkatan Empat di sekolah menengah. UKPS4 terdiri daripada 26 item jenis struktur yang mengandungi lima pecahan konstruk KPS iaitu: mengenal pasti pemboleh ubah dimanipulasikan, pemboleh ubah bergerak balas, dan pemboleh ubah dimalarkan, membina hipotesis, membuat pemerhatian, membuat inferens, dan mendefinisikan secara operasi. Sampel kajian terdiri daripada 60 orang pelajar Tingkatan Empat dari sebuah sekolah bandar di daerah Lawas, Sarawak. Hasil analisis kesahan mendapati polariti item melalui nilai PTMEA-Corr menunjukkan bahawa kesemua 26 item berada $>0.00(+)$. Melalui analisis kesesuaian item, semua item dikekalkan kerana memenuhi syarat dalam salah satu julat outfit MNSQ, Outfit ZSTD dan PTMEA-Corr. Dalam analisis komponen utama (PCA), nilai Raw Variance Explained by Measures $40.6 \%$ dan nilai Unexplained variance dalam kontras pertama hingga kelima di bawah $15 \%$ menunjukkan bahawa instrumen mempunyai keekadimensian yang kuat dan mempunyai kesahan konstruk yang tinggi. Kebolehpercayaan Cronbach Alpha (KR-20) menunjukkan nilai 0.77 (baik), kebolehpercayaan item 0.76 (baik) dan responden 0.73 (mencukupi) dengan nilai pengasingan item 4.78 (baik) dan responden 1.66 (boleh diterima). Kesimpulannya, UKPST4 mempunyai kesahan dan kebolehpercayaan yang baik dalam mengukur penguasaan KPS Tahap Empat pelajar Tingkatan Empat di sekolah menengah.
\end{abstract}

Kata kunci: kesahan dan kebolehpercayaan, Kemahiran Proses Sains Tahap Empat, Model Pengukuran Rasch

\section{Level Four Science Process Skills: An Instrument for Form Four High School Students}

\begin{abstract}
This study aims to determine the validity and reliability of Level Four Science Process Skills Test (L4SPST) instrument using Rasch Measurement Model. The L4SPST was developed to measure the mastery of Level Four Science Process Skills (SPS) of Form Four students in secondary schools. L4SPST consisted of 26 structure type items containing five fractions of SPS constructs namely: identifying the manipulated variables, responding variables, and constant variables, constructing hypotheses, making observations, making inferences, and operational definition. The research sample consisted of 60 Form Four students from a secondary school in Lawas district, Sarawak. The results of the validity analysis found that the polarity of the items through the PTMEA-Corr values showed that
\end{abstract}


all 26 items were $>0.00(+)$. Through item suitability analysis, all items were retained because they met the requirements in one of the MNSQ, Outfit ZSTD and PTMEA-Corr outfit ranges. In the component analysis (PCA), the Raw Variance Explained by Measures value of $40.6 \%$ and the Unexplained variance value in the first to fifth contrast below $15 \%$ indicate that the instrument has a strong dimensional dimension and has high construct validity. The reliability of Cronbach Alpha (KR20) showed a value of 0.77 (good), item reliability of 0.76 (good) and respondent 0.73 (sufficient) with an isolation value of item 4.78 (good) and respondent 1.66 (acceptable). In conclusion, L4SPST has good validity and reliability in measuring the mastery of Level Four SPS among Form Four students.

Keywords: validity, reliability, mastery of SPS Level Four, Rasch Measurement model

\section{Pengenalan}

Kurikulum Standard Sekolah Menengah (KSSM) Sains mengutamakan kaedah inkuiri dan penyelesaian masalah. Dalam proses inkuiri dan menyelesaikan masalah, kemahiran saintifik dan kemahiran berfikir digunakan. Kemahiran saintifik merupakan kemahiran yang penting untuk menjalankan sebarang aktiviti mengikut kaedah saintifik seperti menjalankan eksperimen dan projek. Kemahiran saintifik terdiri daripada kemahiran proses sains (KPS) dan kemahiran manipulatif. KPS merupakan satu proses mental yang menggalakkan pemikiran secara kreatif, analitis dan sistematik. KPS yang merangkumi kemahiran Mengawal Pemboleh ubah, Membuat Pemerhatian, Membuat Inferens, Membina Hipotesis dan Mendefinisikan Secara Operasi merupakan KPS Tahap Empat bagi Tingkatan Empat dan Lima.

Penguasaan Kemahiran proses Sains Tahap Empat (KPST4) penting bagi pelajar untuk mengaplikasikan pengetahuan sains, pengetahuan prosedur dan pengetahuan epistemik dalam mengemukakan soalan menginterpretasikan data, menyelesaikan masalah, membuat perkaitan dan membuat keputusan dalam konteks kehidupan sebenar (Bahagian Pembangunan Kurikulum, 2010). Pernyataan ini disokong oleh Charlesworth dan Lind (2010) yang menyatakan bahawa penguasaan KPS adalah penting untuk memahami masa depan dalam sains dan kemahiran ini bermanfaat dalam menyelesaikan masalah dalam kehidupan seharian. Di samping itu, KPS juga membina kesedaran di kalangan pelajar bahawa penemuan melalui penyelidikan sains adalah usaha manusia berasaskan kemampuan akal untuk memahami fenomena alam ke arah mencapai kesejahteraan hidup.

Kajian-kajian lepas menunjukkan kurangnya penyelidikan tentang pembangunan instrumen untuk mentaksir KPST4 dalam kalangan pelajar sekolah menengah. Contohnya, ujian Penguasaan Kemahiran Proses Sains yang dibangunkan dalam kajian Fitri (2014) adalah untuk mengukur tahap penguasaan kemahiran memerhati, mengelas, membuat inferens, meramal, mengawal pemboleh ubah dan membuat hipotesis dalam kalangan murid Tahun Lima. Justeru, fokus kajian ini adalah untuk membangunkan instrumen untuk menilai penguasaan KPST4 dalam kalangan pelajar Tingkatan Empat di sekolah menengah.

\section{Sorotan Literatur}

Berdasarkan analisis keputusan Sains SPM tahun 2018 dan 2019, didapati keputusan bagi subjek sains menunjukkan penurunan dari segi peratus lulus manakala peratus gagal dan GPMP adalah meningkat (Jadual 1). Dapatan kajian lepas (Aktamis \& Ergin, 2008; Capp, 2009; Kanli \& Yagbasan, 2007; Okebukola, 1986; Rohana \& Shaharom, 2008; Sharifah \& Rohaida, 2005, Ten, 2004) mendapati pencapaian pelajar dalam sains mempunyai hubungan dengan penguasaan dalam KPS. Pelajar yang tidak menguasai KPS seperti mengenal pasti pemboleh ubah dimanipulasikan, pemboleh ubah bergerak balas, dan pemboleh ubah dimalarkan, membina hipotesis, membuat pemerhatian, membuat inferens, dan mendefinisikan secara operasi didapati memperoleh pencapaian yang rendah dalam mata pelajaran sains. 
Jadual 1: Pencapaian Sains SPM tahun 2018 dan 2019

\begin{tabular}{cccc}
\hline Tahun & Lulus (\%) & Gagal (\%) & GPMP \\
\hline 2018 & 91.1 & 8.9 & 5.00 \\
2019 & 89.9 & 10.1 & 5.14 \\
\hline
\end{tabular}

Sumber: KPM (2020)

Hasil kajian oleh Kassim et al. (2003) juga menunjukkan tahap penguasaan pencapaian Kimia di kalangan pelajar adalah sederhana, begitu juga dengan tahap penguasaan kemahiran proses sains, khususnya kemahiran membuat inferens dan mengenal pasti pemboleh ubah, Namun begitu, fokus kajian lepas bukan secara spesifik kepada KPS tahap empat bagi subjek Sains di kalangan pelajar tingkatan empat. KPS yang diukur hanya melibatkan subjek Sains Tulen seperti Kimia, Biologi, dan Fizik tetapi bukan untuk subjek Sains Tingkatan Empat (Meor \& Nor, 2016). Maka, dalam kajian ini penyelidik membangunkan instrumen iaitu Ujian Kemahiran Proses Sains Tahap Empat (UKPST4) bagi menilai tahap penguasaan pelajar dalam KPS tahap empat di kalangan pelajar Sains Tingkatan Empat.

\section{Kemahiran Proses Sains Tahap Empat}

Ujian yang dibangunkan adalah menguji lima konstruk KPST4 iaitu kemahiran mengenal pasti pemboleh ubah dimanipulasi, bergerak balas, dan dimalarkan, membina hipotesis, membuat pemerhatian, membuat inferens, dan mendefinisikan secara operasi. Penerangan bagi setiap komponen KPST4 adalah diberikan dalam Jadual 2.

Jadual 2: Standard Tahap 4 Kemahiran Proses Sains

\begin{tabular}{|c|c|}
\hline Kemahiran Proses Sains & Tahap 4 (Tingkatan 4-5) \\
\hline Mengawal pemboleh ubah & $\begin{array}{l}\text { - Menukarkan pemboleh ubah yang dimalarkan kepada } \\
\text { pemboleh ubah dimanipulasikan dan menyatakan } \\
\text { pemboleh ubah bergerak balas yang baharu. }\end{array}$ \\
\hline Membuat hipotesis & $\begin{array}{l}\text { - Menerangkan satu hasil penyiasatan yang dijangka } \\
\text { daripada penyiasatan saintifik yang direka. }\end{array}$ \\
\hline Memerhati & $\begin{array}{l}\text { - Membuat pemerhatian kualitatif dan kuantitatif untuk } \\
\text { membuat generalisasi berdasarkan pola atau urutan } \\
\text { ke atas objek atau fenomena. } \\
\text { Mengemukakan dapatan hasil pemerhatian lanjutan } \\
\text { ke atas objek atau fenomena secara analitis dan } \\
\text { spesifik. }\end{array}$ \\
\hline Membuat inferens & $\begin{array}{l}\text { Menjana pelbagai kemungkinan bagi menjelaskan } \\
\text { situasi yang kompleks. } \\
\text { Menjelaskan hubung kait atau pola antara pemboleh } \\
\text { ubah yang diperhatikan dengan ukuran yang dibuat } \\
\text { untuk sesuatu penyiasatan. }\end{array}$ \\
\hline Mendefinisikan secara operasi & $\begin{array}{l}\text { - Menjelaskan tafsiran yang dibuat tentang pemilihan } \\
\text { peralatan atau kaedah tentang apa yang diperhatikan. }\end{array}$ \\
\hline
\end{tabular}

(Sumber: Bahagian Pembangunan Kurikulum. (2018), m/s 14-18.

\section{Model Pengukuran Rasch}

Model Pengukuran Rasch (MPR) merupakan teknik psikometri yang dibangunkan untuk meningkatkan ketepatan instrumen yang dibina, memantau kualiti instrumen dan mengira prestasi responden (Boone, 2016). MPR adalah model yang paling mudah dalam Teori Respons Item kerana ia merupakan model probabilistik yang menilai kesukaran item dan keupayaan seseorang yang dapat diskorkan pada skala 
yang sama (Deane et al., 2016). Model Rasch menganggarkan kebarangkalian seseorang untuk memilih item atau kategori tertentu (Mahmud \& Porter, 2015). Kesukaran item dan kemampuan seseorang diukur dalam skala logit dalam Model Rasch (Runnels, 2012). Analisis daripada Model Rasch dapat memaklumkan kepada penyelidik mengenai kebolehpercayaan responden dan item, pengasingan item dan responden, serta nilai Cronbach's alpha. Sementara itu, kesahan konstruk sesebuah instrumen boleh dinilai melalui kesesuaian item dan responden, dan unidimensionaliti. Oleh itu, konsep utama yang disebutkan di atas akan digunakan oleh penyelidik untuk menilai kebolehpercayaan dan kesahan instrumen UKPST4 menggunakan analisis Rasch.

\section{Objektif Kajian}

Tujuan kajian ini dijalankan adalah untuk menilai kebolehpercayaan dan kesahan instrumen Ujian Kemahiran Proses Sains Tahap Empat (UKPST4) dengan menggunakan Model Pengukuran Rasch (MPR). Secara khususnya, objektif kajian adalah untuk:

i. Menilai kebolehpercayaan instrumen UKPST4 menggunakan analisis Rasch.

ii. Menilai kesahan instrumen UKPST4 menggunakan analisis Rasch.

\section{Kepentingan Kajian}

Kajian ini penting untuk menambahkan maklumat dan rujukan yang berguna kepada tinjauan literatur, khususnya dalam pembangunan instrumen KPS dalam subjek Sains. Di samping itu, kajian ini juga menyediakan instrumen kajian yang sah dan boleh dipercayai untuk mengukur penguasaan KPS Tahap Empat pelajar yang boleh dijadikan sebagai rujukan yang berguna untuk penyelidik lain yang ingin menjalankan kajian yang sama.

\section{Metod Kajian}

\section{Instrumentasi}

Instrumen ujian KPS Tahap Empat (UKPST4) adalah terdiri daripada 26 item soalan berbentuk struktur. Pengagihan item dalam UKPST4 adalah ditunjukkan dalam Jadual 3. Item soalan yang dibina adalah berdasarkan kepada isi kandungan DSKP Sains Tingkatan Empat tentang KPS tahap empat (Bahagian Pembangunan Kurikulum, 2018). Penyelidik boleh menggunakan set ujian pra dan ujian pasca yang sama bagi melihat perkembangan dan peningkatan murid dalam menguasai KPS tahap empat. Cadangan masa untuk menjawab ujian adalah selama 1 jam 30 minit, iaitu bersamaan dengan tiga minit bagi setiap soalan.

Jadual 3: Pengagihan Item-item Dalam Instrumen Ujian KPS Tahap Empat Sains Tingkatan Empat

\begin{tabular}{lc}
\hline \multicolumn{1}{c}{ KPS Tahap Empat } & Bilangan Soalan \\
\hline $\begin{array}{l}\text { Mengenal pasti pemboleh ubah dimanipulasikan, bergerak } \\
\text { balas, dan dimalarkan }\end{array}$ & 7 \\
Membina hipotesis & 5 \\
Membuat pemerhatian & 3 \\
Membuat inferens & 5 \\
Mendefinisikan secara & 6 \\
operasi & $\mathbf{2 6}$ \\
\hline
\end{tabular}




\section{SampelKajian}

Sampel kajian adalah terdiri daripada 60 orang pelajar Tingkatan Empat daripada sebuah sekolah menengah bandar di daerah Lawas, Sarawak.

\section{Prosedur untuk Menganalisis Data}

Bagi menentukan aspek kesahan konstruk dan kebolehpercayaan item, perisian WINSTEPS versi 3.73 digunakan. Hal ini bagi memastikan jaminan kualiti instrumen dan ketepatan data yang diperoleh penyelidik sebelum digunakan dalam konteks kajian sebenar.

Pertamanya, analisis nilai PTMEA-CORR dilakukan untuk mengenal pasti polariti. Nilai PTMEACORR yang positif menunjukkan bahawa item dapat mengukur dengan baik apa yang ingin diukur dan sebaliknya jika nilainya adalah negatif. Kesesuaian item pula dianalisis dengan merujuk kepada nilai Outfit MNSQ, Outfit ZSTD dan PTMEA-CORR (Bond \& Fox, 2015; Boone et al., 2014; Waugh, 2012). Nilai kesesuaian item ini menunjukkan sama ada item tersebut dapat menjalankan pengukuran yang sepatutnya (Sumintono \& Widhiarso, 2015). Item yang tidak berada dalam lingkungan julat Indeks Kesesuaian Item (Jadual 4) perlu diubah suai atau digugurkan agar nilai kesesuaian item dapat ditingkatkan (Sumintono \& Widhiarso, 2015).

Jadual 4: Indeks Kesesuaian Item

\begin{tabular}{ll}
\hline Statistik & Indeks \\
\hline Outfit MNSQ & $0.50-1.50$ \\
Outfit ZSTD. & $-2.00-2.00$ \\
PTMEA-CORR & $0.40-0.85$ \\
\hline
\end{tabular}

Sumber: Boone et al. (2014)

Selain itu, model Rasch juga dapat menunjukkan kesesuaian responden berdasarkan nilai dengan merujuk kepada nilai 'MEASURE', Outfit MNSQ, dan Outfit ZSTD (Edwards \& Alcock, 2010). Nevin et al. (2015) menegaskan bahawa sekiranya nilai Outfit ZSTD melebihi 2.0 dan nilai MEASURE adalah tinggi, wujud kebarangkalian bahawa pelajar yang cemerlang tidak menjawab dengan berhatihati item yang rendah arasnya. Jika nilai Outfit ZSTD melebihi 2.0 tetapi nilai MEASURE pula rendah, berkemungkinan bahawa pelajar yang berkeupayaan rendah dapat menjawab item yang 'susah' dengan betul. Oleh itu, responden yang tidak sesuai akan disingkirkan bagi meningkatkan kesahan instrumen (Lamoureux et al., 2008).

Penyelidik turut menilai keekadimensian instrumen untuk memastikan instrumen benar-benar dapat mengukur pemikiran sains keusahawanan (Shea et al., 2009; Sumintono \& Widhiarso, 2015). Analisis Komponen Utama (Principal Component Analysis, PCA) menyediakan kriteria keekadimensian berdasarkan 'raw variance explained by measures' (Sumintono dan Widhiarso, 2015). Nilai 'raw variance explained by measures' yang diterima perlu melebihi $20 \%$, baik jika melebihi $40 \%$ dan cemerlang jika melebihi $60 \%$. Sementara itu, nilai bagi 'unexplained variance in first contrast' tidak boleh melebihi $15 \%$.

Jadual 5: Keekadimensian berdasarkan Raw Variance Explained by Measures

\begin{tabular}{cc}
\hline Nilai & Tafsiran \\
\hline$>20 \%$ & Diterima \\
$>40 \%$ & Baik \\
$>60 \%$ & Cemerlang
\end{tabular}

Sumber: Sumintono dan Widhiarso (2015) 
Dari aspek kebolehpercayaan pula, pengkaji merujuk kepada Sumintono dan Widhiarso (2015) bagi nilai Alpha Cronbach (KR-20), indeks kebolehpercayaan item dan responden serta pengasingan item dan responden (Jadual 5).

Jadual 5: Kebolehpercayaan dalam Analisis Rasch

\begin{tabular}{|c|c|c|}
\hline Pertunjuk & Nilai Alpha & Interpretasi \\
\hline \multirow{5}{*}{$\begin{array}{l}\text { a. Nilai Alpha Cronbach } \\
\text { Mengukur kebolehpercayaan antara subjek kajian dan } \\
\text { item keseluruhan }\end{array}$} & $<0.5$ & Rendah \\
\hline & $0.5-0.6$ & Sederhana \\
\hline & $0.6-0.7$ & Baik \\
\hline & $0.7-0.8$ & Tinggi \\
\hline & $>0.8$ & Sangat Tinggi \\
\hline \multirow[t]{5}{*}{ b. Nilai Kebolehpercayaan Subjek kajian dan Item } & $<0.67$ & Lemah \\
\hline & $0.67-0.80$ & Cukup \\
\hline & $0.80-0.90$ & Baik \\
\hline & $0.91-0.94$ & Sangat Baik \\
\hline & $>0.94$ & Istimewa \\
\hline c. Separation & $\begin{array}{l}\text { Pengumpulan } \\
\text { subjek kajian } \\
\text { dan item }\end{array}$ & $\begin{array}{l}\text { Semakin besar } \\
\text { nilai } \\
\text { Separation, } \\
\text { semakin } \\
\text { berkualiti } \\
\text { instrumen, } \\
\text { kumpulan } \\
\text { subjek kajian } \\
\text { dan item }\end{array}$ \\
\hline
\end{tabular}

Sumber: Sumintono dan Widhiarso (2015)

\section{Hasil Kajian}

\section{Kesahan Ujian KPS Tahap Empat Sains Tingkatan Empat}

Kesahan merupakan konsep yang penting dalam konteks pengukuran sesuatu konstruk. Oleh itu, instrumen UKPST4 perlu melalui proses kesahan muka (face validity) dan kesahan kandungan (contain validity) bagi menyemak aspek bahasa, struktur dan susunan ayat yang sesuai ataupun tidak dengan komponen dalam pengukuran dan maksud item-item yang ditanya (Mohd. Najib Abdul Ghafar, 2003).

Jadual 6: Panel Kesahan Kandungan Ujian KPS Tahap Empat (UKPST4) Sains Tingkatan Empat

\begin{tabular}{lllll}
\hline Bil & Nama & Wakil & Jawatan & Kepakaran \\
\hline 1 & Pakar A & Guru & $\begin{array}{l}\text { Ketua Bidang Sains dan } \\
\text { Matematik }\end{array}$ & $\begin{array}{l}\text { Sains Sekolah } \\
\text { Menengah Atas }\end{array}$ \\
& \multirow{2}{*}{ Pakar B } & Guru & $\begin{array}{l}\text { Jurulatih Utama Sains } \\
\text { Daerah }\end{array}$ & $\begin{array}{l}\text { Sains Sekolah } \\
\text { Menengah Atas }\end{array}$ \\
& & &
\end{tabular}


Bagi tujuan memperoleh kesahan muka, penyelidik telah melaksanakan satu sesi temu bual ringkas bersama subjek kajian yang dipilih secara rawak di dalam kelas. Penyelidik mendapati subjek kajian bersetuju bahawa mereka dapat memahami maksud dan arahan soalan dengan baik. Selain itu, mereka juga menyatakan penggunaan rajah adalah sesuai dan jelas. Bagi mengesahkan kandungan item-item instrumen ini, penyelidik menggunakan khidmat dua orang panel pakar. Jadual 6 menunjukkan panel yang telah dilantik. Setiap panel telah diberikan borang yang diadaptasi daripada borang Penilaian Kesahan Kandungan Ujian KPS Tahap Empat Sains Tingkatan Empat. Seterusnya, Jadual 7 pula menunjukkan dapatan daripada panel pakar terhadap kesahan kandungan instrumen ini mengikut aspek penilaian yang diberikan.

Jadual 7: Dapatan Panel Kesahan Kandungan Ujian KPS Tahap Empat Sains Tingkatan Empat Mengikut Aspek

\begin{tabular}{llccc}
\hline Bil & Pakar & \multicolumn{3}{c}{ Peratus (\%) persetujuan mengikut aspek } \\
\cline { 3 - 5 } & & Keakuran & Ketepatan dan Kejelasan & Kesesuaian \\
\hline 1 & Pakar A & 100 & 100 & 100 \\
2 & Pakar B & 100 & 100 & 100 \\
\hline
\end{tabular}

\section{Kesesuaian Item Mengukur Konstruk}

\section{Polariti Item Melalui Nilai Point Measure Correlation (PTMEA CORR)}

Pemeriksaan nilai Point Measure correlation (PTMEA CORR.) adalah bagi mengesan polariti item bertujuan untuk menguji sejauh mana pembinaan kostruk mencapai matlamatnya. Menurut Bond dan Fox (2007), nilai PTMEA-CORR yang tinggi iaitu dalam julat 0.4-0.85 menunjukkan item tersebut berupaya untuk membezakan kemampuan antara subjek kajian serta pembinaan item dapat mengukur apa yang patut diukur. Namun Bond \& Fox (2015) menyatakan bahawa jika nilai PTMEA CORR adalah nilai positif (+), ia menunjukkan item tersebut mengukur konstruk yang ingin diukur. Sekiranya nilai yang diperoleh sebaliknya, negatif (-) ia bermaksud item yang dibangunkan tidak mengukur konstruk yang ingin diukur. Maka ia perlu dibaiki atau digugurkan kerana item tidak menjurus kepada soalan atau sukar dijawab oleh responden. Nilai PTMEA-CORR dipersembahkan seperti dalam Rajah 1 .

Rajah 1: Analisis nilai polariti item

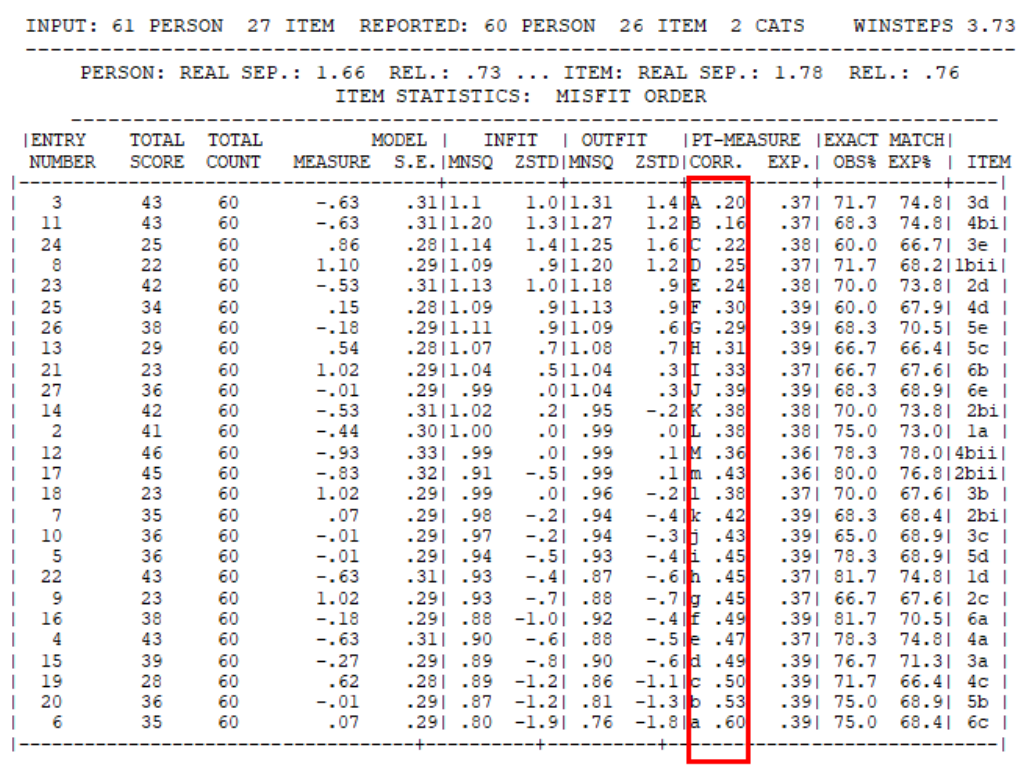


Dapatan menunjukkan bahawa semua item dalam UKPST4 mempunyai nilai PTMEA-CORR yang positif. Maka hal ini disokong oleh Bond dan Fox (2015) yang menyatakan bahawa item yang mempunyai nilai PTMEA-CORR yang positif tersebut bermaksud ia mengukur konstruk yang ingin diukur.

\section{Kesesuaian Item}

Boone, et al. (2014) mengemukakan dua kriteria yang digunakan untuk memeriksa kesesuaian item, iaitu:

i. $\quad$ Nilai Outfit Mean Square (MNSQ) yang diterima: $0.5<\mathrm{MNSQ}<1.5$

ii. Nilai pakaian Z-standard (ZSTD) yang diterima: $-2.0<$ ZSTD $<+2.0$

Sekiranya item pada dua kriteria tersebut tidak dipenuhi, hal ini bermaksud item tersebut tidak sesuai dan perlu disemak semula atau diganti. Berbeza dengan tahap kesukaran item yang konsisten, tahap kesesuaian item ini sangat dipengaruhi oleh ukuran sampel. Kesalahan dalam kunci jawapan, bilangan individu yang tidak berhati-hati menjawab soalan, dan soalan yang mempunyai indeks diskriminasi yang rendah dapat mengurangkan nilai kesesuaian item. Secara keseluruhannya, keputusan nilai outfit MNSQ adalah seperti dalam Jadual 7:

Jadual 7: Kesesuaian Item

\begin{tabular}{clc}
\hline Nilai Outfit Mean-Square & $\begin{array}{l}\text { Kesan Ke Atas Pengukuran } \\
\text { Item }\end{array}$ & Nombor Item \\
\hline$>2.0$ & $\begin{array}{l}\text { Item perlu dibaiki atau digantikan } \\
\text { Boleh diterima dan tidak } \\
\text { menjejaskan }\end{array}$ & Tiada \\
$1.5-2.0$ & $\begin{array}{l}\text { Konsisten untuk pengukuran item } \\
0.6-1.4\end{array}$ & $\begin{array}{c}\text { Semua item } \\
\text { Item perlu dibaiki atau digantikan }\end{array}$ \\
\hline
\end{tabular}

\section{Kesesuaian Subjek Kajian}

Berdasarkan analisis pengukuran Rasch Model, kesahan subjek kajian dianalisis bagi memastikan sesuatu item yang digunakan mampu untuk menghasilkan keputusan yang konsisten pada kumpulan yang berlainan (Summintono \& Widhiarso, 2014). Bagi mengesan subjek kajian yang tidak sepadan, analisis kesesuaian subjek kajian diperoleh dan disemak melalui jadual kesesuaian subjek kajian seperti ditunjukkan dalam Jadual 8. Pemeriksaan terhadap nilai min kuasa dua (MNSQ), skor-z (ZSTD) dan korelasi juga dilakukan.

Jadual 8: Ketidaksesuaian Subjek Kajian Melalui Analisis Statistik fit person

\begin{tabular}{cccc}
\hline Nombor Subjek Kajian & Outfit MNSQ & Outfit ZSTD & PTMEA-CORR \\
\hline 55 & 1.59 & 1.4 & -0.30 \\
52 & 1.51 & 1.5 & -0.22 \\
48 & 1.51 & 2.0 & -0.22 \\
\hline
\end{tabular}

Seramai 57 orang subjek kajian memberikan jawapan yang mempunyai nilai logit MNSQ dan Point Measure Correlation (PTMEA CORR) di dalam julat yang ditetapkan dan dapat memberikan hasil dapatan kajian yang berkualiti. Pada masa yang sama subjek kajian yang bernombor 55, 52, dan 48 tidak padan secara statistik kerana ketiga-tiga nilai korelasi berada di luar julat yang ditetapkan. Responden yang memberikan bacaan PTMEA-CORR yang negatif menunjukkan mereka membuat keputusan luar daripada kebiasaan. Namun, subjek kajian ini masih dikekalkan atas sebab berkemungkinan subjek kajian cuai semasa menjawab soalan UKPST4 (Hamzah, Khoiry, Arshad, Badaruzzaman \& Tawil, 2012). 
Berdasarkan analisis kesesuaian subjek kajian dalam kajian rintis dapat memberi gambaran kepada penyelidik untuk memastikan bahawa subjek kajian dalam kumpulan yang terlibat semasa kajian lapangan tidak cuai, tidak konsisten dan tidak meniru semasa menjawab UKPST4. Hal ini turut dipersetujui oleh Yasin et al. (2015) yang menyatakan bahawa kesesuaian subjek kajian merupakan aspek terpenting yang perlu diberi penekanan oleh penyelidik kerana subjek kajian yang didapati sah perlu dikekalkan dalam kajian dan subjek kajian yang tidak sesuai perlu digugurkan.

Manakala Hair, Anderson, Tatham \& Black (1998) berpendapat subjek kajian yang menyumbang kepada tidak menjawab soalan perlu digugurkan bagi mendapatkan dapatan statistik yang berkualiti. Hair et al. (1998) turut menyatakan faktor utama yang menyebabkan kurangnya kesahan dapatan kajian adalah disebabkan terdapat kebarangkalian subjek kajian yang tidak serius untuk menjawab soalan. Oleh hal yang demikian, subjek kajian-subjek kajian yang mempunyai skor yang sama untuk semua soalan perlu digugurkan bagi meningkatkan kualiti dapatan kajian.

\section{Unidimensionaliti}

Hasil analisis unidimensionaliti mendapati instrumen UKPST4 dalam kajian ini mempunyai nilai Raw variance explained by measures $40.6 \%$ dan Unexplained variance in 1 st contrast $7.7 \%$ adalah tidak melebihi had kawalan seperti yang ditetapkan oleh Model Pengukuran Rasch. Manakala nilai Eigen yang terletak pada Unexplained variance in 1st contrast ialah 2.5 yang tidak melebihi 5. Ini menunjukkan instrumen ini bebas daripada sebarang kekeliruan dari segi tujuan kajian ini dilakukan dan tidak wujud dimensi kedua bagi instrumen UKPST4. Dapatan analisis diilustrasikan seperti Rajah 3 .

\section{Rajah 2: Analisis Komponen Utama}

\begin{tabular}{|c|c|c|c|c|c|}
\hline \multicolumn{6}{|c|}{ STANDARDIZED RESIDUAL variance (in Eigenvalue units) } \\
\hline & & \multicolumn{2}{|c|}{---- Empirical --. } & \multicolumn{2}{|c|}{ Modeled } \\
\hline Total raw variance in observations & $=$ & 32.8 & $100.0 \%$ & & $100.0 \%$ \\
\hline Raw variance explained by measures & $=$ & 25.5 & $40.6 \%$ & & $20.3 \%$ \\
\hline Raw variance explained by persons & $=$ & 2.9 & $8.8 \%$ & & $8.6 \%$ \\
\hline Raw Variance explained by items & $=$ & 3.9 & $11.9 \%$ & & $11.7 \%$ \\
\hline Raw unexplained variance (total) & $=$ & 26.0 & $79.4 \%$ & $100.0 \%$ & $79.7 \%$ \\
\hline Unexplained variance in 1 st contrast & $=$ & 2.5 & $7.7 \%$ & $9.7 \%$ & \\
\hline Unexplained variance in 2 nd contrast & $=$ & 2.5 & $7.5 \%$ & $9.4 \%$ & \\
\hline Unexplained variance in 3 rd contrast & $=$ & 2.2 & $6.7 \%$ & $8.5 \%$ & \\
\hline Unexplained variance in 4 th contrast & $=$ & 2.0 & $6.0 \%$ & $7.6 \%$ & \\
\hline Unexplained variance in 5 th contrast & $=$ & 1.8 & $5.4 \%$ & $6.8 \%$ & \\
\hline
\end{tabular}

\section{Kebolehpercayaan dan Nilai Pengasingan Item dan Responden}

Secara keseluruhan, kebolehpercayaan item dan subjek kajian, pengasingan item dan subjek kajian serta nilai Cronbach Alpha diringkaskan seperti Jadual 9.

Jadual 9: Kebolehpercayaan item dan subjek kajian, pengasingan item dan subjek kajian dan nilai Cronbach Alpha

\begin{tabular}{lccc}
\hline & $\begin{array}{c}\text { Model } \\
\text { Pengukuran } \\
\text { Rasch }\end{array}$ & UKPST4 & Taksiran \\
\hline Nilai Cronbach Alpha & $>0.7$ & 0.77 & Baik \\
Kebolehpercayaan Item & $>0.7$ & 0.76 & Baik \\
Kebolehpercayaan Subjek kajian & $>0.7$ & 0.73 & Mencukupi \\
Nilai Pemisah Item & $>2.0$ & 4.78 & Baik \\
Nilai Pemisah Subjek kajian & $>2.0$ & 1.66 & Boleh diterima \\
Skor Esktrem & Tiada & Tiada & Tiada
\end{tabular}


$\begin{array}{llll}\text { Disorder Threshold } & \text { Tiada } & \text { Tiada } & \text { Tiada }\end{array}$

\section{Perbincangan Kajian}

Secara keseluruhannya, analisis kesahan instrumen telah dijalankan bagi menentukan aspek polariti item, kesesuaian item dan responden serta unidimensionaliti. Analisis PTMEA-CORR yang positif menunjukkan bahawa semua item bergerak dalam satu arah yang sama dalam mentafsir konstruk yang ingin diukur (Bond \& Fox, 2015) dalam KPS tahap empat. Melalui analisis kesesuaian item, kesemua item dalam instrumen UKPST4 dikekalkan kerana berada dalam lingkungan julat salah satu kriteria Outfit MNSQ, Outfit ZSTD dan PTMEA-CORR. Bagi kesesuaian responden, daripada 60 orang, hanya seramai tiga orang responden yang menunjukkan ketidaksesuaian dan skor yang ekstrem dengan memberikan bacaan PTMEA-CORR yang negatif. Hal ini menunjukkan mereka membuat keputusan luar daripada kebiasaan. Namun, subjek kajian ini masih dikekalkan atas sebab berkemungkinan subjek kajian cuai semasa menjawab soalan UKPST4 (Hamzah, Khoiry, Arshad, Badaruzzaman \& Tawil, 2012).

Daripada aspek kebolehpercayaan, instrumen UKPST4 mempunyai nilai Alfa Cronbach pada tahap baik (0.77), nilai kebolehpercayaan item yang baik (0.76) dan kebolehpercayaan responden yang mencukupi (0.73). Dapatan ini menunjukkan bahawa kebolehpercayaan instrumen UKPST4 dalam menilai penguasaan KPS Tahap Empat pelajar Tingkatan Empat di sekolah menengah berada pada tahap boleh diterima dan baik.

\section{Kesimpulan}

Pembangunan instrumen perlu dilakukan dengan tepat dan betul daripada aspek kesahan dan kebolehpercayaan bagi memastikan instrumen yang dibangunkan dapat digunakan berulang kali. Instrumen yang telah dibina dengan betul pasti tidak akan menghadapi masalah dalam mengukur pemboleh ubah yang dikaji (Azrilah et al., 2015). Senario ini pastinya akan membantu penyelidik untuk membuat keputusan daripada analisis dapatan tersebut. Tambahan lagi, dapatan ini memberi sandaran kepada penyelidik lain agar analisis Rasch terhadap instrumen UKPST4 dapat dilakukan bagi pelajar di kawasan-kawasan lain. Tuntasnya, hasil analisis kesahan dan kebolehpercayaan menggunakan Model Pengukuran Rasch berjaya menunjukkan bahawa instrumen UKPST4 adalah sah dan boleh dipercayai untuk mengukur penguasaan KPS Tahap Empat pelajar Tingkatan Empat di sekolah menengah.

\section{Rujukan}

Aktamis, H. \& Ergin, O. (2008). The Effect of Scientific Process Skills Education on StudentsScientific Attitudes and Academic Achievement. Asia-Pacific Forum on ScienceTeaching.

Awelani, M. R. (2002). A study of the application of science process skills in secondary schools in the free states province. Unpublished doctoral thesis, University of Pretoria.

Azrilah, A. A., Mohd Saidfudin, M., \& Azami, Z (2015). Asas model pengukuran Rasch: Pembentukan skala \& struktur pengukuran. Penerbit UKM.

Bahagian Pembangunan Kurikulum (2010). Kurikulum Bersepadu Sekolah Menengah: Spesifikasi Kurikulum Sains Tingkatan 5. Kementerian Pelajaran Malaysia.

Bahagian Pembangunan Kurikulum. (2016). Panduan Pengajaran Dan Pembelajaran Berasaskan Inkuiri. Kementerian Pendidikan Malaysia.

Bahagian Pembangunan Kurikulum. (2018). Dokumen Standard Kurikulum dan Pentaksiran Sains Tingkatan Empat. Kementerian Pelajaran Malaysia..

Bond, T. G., \& Fox, C. M. (2015). Applying the Rasch Model: Fundamental measurement in the Human Sciences. Routledge. https://doi.org/10.1017/CBO9781107415324.004 
Boone, W. J., Yale, M. S., \& Staver, J. R. (2014). Rasch analysis in the human sciences. In Rasch Analysis in the Human Sciences. Springer. https://doi.org/10.1007/978-94-007-6857-4

Boone, W. J. (2015). Rasch Analysis Ffor Instrumen Development: Why, When, and How? CBE- Life Sciences Education.

Brophy, J. 1998. Motivating students to Learn. McGraw Hill.

Brown, A. L (1987). Metacognition, Executive Control, Self-regulation and Other More Mysterious Mechanisms. Dalam Weinert, F.E. \& Kluwe, R.H (eds.). Metacognition,

Deane, T., Nomme, K., Jeffery, E., Pollock, C., \& Birol, G. (2016). Development of the statistical reasoning in biology concept inventory (SRBCI). CBE Life Sciences Education, 15(1), 1-13. https://doi.org/10.1187/cbe.15-06-0131

Fosnot, C. T. (1989). Enquiring Teachers, Enquiring Learners: A Constructivist Approach to Teaching. Teachers College Press.

Fraenkel, J. R. \& Wallen, N.E. (1996). How to Design and Evaluate Research. McGraw Hill Inc.

Fitri Shahwaliah Binti Su'ut. (2014). Penguasaan Kemahiran Proses Sains Dan Pencapaian Matapelajaran Sains Dalam Kalangan Murid Tahun Lima Sekolah Kebangsaan Di Kudat.

Gagne, R.M. (1965). Psychological Review. Journal Research in Science Teaching. 75(3): 177-191.

Hasnah Mohamed. (2012). Kesan Penggunaan Perisian Pendidikan Terhadap Pencapaian Pelajar Merentasi Gaya Kognitif. Tesis Doktor Falsafah, Universiti Teknologi Malaysia.

Kassim, Abu Hassan and Hussin, Rohana. (2003). Tahap Penguasaan Kemahiran Proses Sainsdan Hubungannya Dengan Pencapaian Kimia Di Kalangan Pelajar Tingkatan Empat Daerahjohor Bahru.In: Seminar Memperkasakan Sistem Pendidikan, 19-21 October 2003,Puteri Pan Pasific, Johor Bahru.

Kementerian Kewangan Ekonomi. (1986). Laporan ekonomi 1986/87. Jabatan Percetakan Negara.

Kementerian Pendidikan Malaysia. (2016). Buku Penerangan Kurikulum Standard Sekolah Menengah (Manual Book of Secondary School Standard Curriculum). Bahagian Pembangunan Kurikulum,

Langworthy, M. (2013). 21st Century Learning Design: Learning that matters. Dalam https://www.internationalpublishers.org/images/pressreleases/EducationalPublishing/m_langwort hy.pdf. 18 November 2020.

Lee, E., \& Hannafin, M. J. (2016). A Design Framework for Enhancing Engagement in Student-centered Learning: Own It, Learn It, and Share It. Education Tech Research Dev, 64: 707-734.

Martin, L, West, J. \& Bill, K. (2008). Incorporating problem-based learning strategies to develop learner autonomy and employability skills in sport science undergraduate. Journal of Hospitality, Leisure, Sport and Tourism Education, 7:18-30.

Meor Ibrahim Bin Kamaruddin \& Nor Ashikin Binti Mohd Razali. (2019). Tahap Penguasaan Kemahiran Membina Inferens Dan Mentafsir Data Dalam Kalangan Pelajar Tahun Satu, Dua Dan Empat Program Kimia. Universiti Teknologi Malaysia.

Mohd Najib Abd Ghafar \& Mohd Yusuf Arshad. (1995). Peningkatan kemahiran saintifik melalui interaksi di bilik darjah. Seminar Kebangsaan Pendidikan Guru Ke-10, 18-19 December, Skudai, Johor.

National Curriculum Council. (1989). National science education standards. The National Academic Press.

Needham, R. \& Hills, J. (1987). Pupils and paradigms: A review of literature related to concept development in adolescent science students. Journal of Studies in Science Education, 5: 61-84.

Padilla, M., Cronin, L. \& Twiest, M. (1980). The development and validation of the test of basic process skills. National Association of Research in Science Teaching. 15-17 February, French Lick, IN.

Padilla, M. J. (1990). The science process skills. Research matters-To the science teacher, No. 9004. Reston, VA: National Association for Research in Science Teaching (NARST).

Paradesa Ravesh. 2015. Kemampuan Berpikir Kritis Matematis Mahasiswa Melalui Pendekatan Konstruktivisme Pada Matakuliah Matematika Keuangan. Jurnal Pendidikan Matematika RAFA, 1 (2): 306-325.

Sumintono, B., \& Widhiarso, W. (2015). Aplikasi pemodelan RASCH pada assessment pendidikan (Issue September). Penerbit Trim Komunikata.

Tobin K.G. dan Capie W. (1980). "Teaching Process Skill In The Middle School, School Science And Mathematics." Journal of Research In Science Teaching. 590-600. 
Tobin, K. G. dan Capie, W. (1982). "Relationship between formal reasoning ability, focus of control, academic engagement and integrated process skills achievement." Journal of Research Teaching. 19: 113-121.

Vantipa, R, Muhammad, N.A, Said, M. (1996). Science Process Skills Performance Among Students In Malaysia, The Philippines and Thailand." SEAMEO Regional Centre For Education In Science and Mathematics.

Vygotsky, L. S. (1987). The collected works of L. S. Vygotsky: Vol. 1. Problems of General Psychology. In R. W. Rieber \& A. S. Carton,( Eds.). Plenum.

Wilder, M. \& Shuttleworth, P. (2004). Cell Inquiry: A 5E Learning Cycle Lesson. Science Activities, 41(1): 37-43. 